\title{
Interfaces of informality
}

\section{Eduardo Ascensão}

To cite this article: Eduardo Ascensão (2016) Interfaces of informality, City, 20:4, 563-580, DOI: 10.1080/13604813.2016.1193337

To link to this article: https://doi.org/10.1080/13604813.2016.1193337

曲 Published online: 13 Sep 2016.

Submit your article to this journal $\pi$

III Article views: 373

View Crossmark data $\nearrow$

47 Citing articles: 4 View citing articles 진 


\title{
Interfaces of informality When experts meet informal settlers
}

\section{Eduardo Ascensão}

\begin{abstract}
What happens at the interface of states and urban poor populations that live in informal settlements? How are academic disciplines, such as law, architecture or economics, and technical instruments, such as computer software, summoned to the interactions between experts from state or city governments and the laypeople whose housing and lives the former's work is meant to improve? This paper reflects on these questions as it examines two different experiments, one historical and another from the recent past, in housing provision or amelioration for the residents of informal settlements. In post-revolutionary Portugal, the SAAL (Serviço de Apoio Ambulatório Local) bousing program (1974-76) included 'technical' brigades of legal, architectural and economic experts tasked to belp shanty town dwellers improve their housing conditions, either by assisted self-building or classic new-build. It was a clear example of the progressive urban politics of the time, or dialogical technical democracy avant la lettre. Some 30 years later, in Lisbon during the late 2000s, as a part of an urban regeneration program devised within the framework of multicultural urban politics and delegative forms of democracy, a detailed survey of non-and sub-standard houses was carried out with a bespoke computer software, which aimed at representing the technical feasibility of rebabilitation, rather than replacement, of those dwellings. Both experiments constituted platforms with the stated objective of working for the community and through which new state-citizen relationships were to be forged with the urban poor, but how were the latter's knowledges and wishes integrated?
\end{abstract}

Key words: urban informality, state intervention, experts and slum dwellers, assisted selfbuilding, assessment of non-standard housing

\section{Introduction}

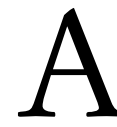

$\mathrm{t}$ the heart of Michel Callon, Pierre Lascoumes and Yannick Barthe's idea of 'technical democracy' lies the wish for a democratic arrangement between the multiple agencies of human and non-human actors in techno-scientific endeavors. A crucial element of these democratic arrangements involves the question of how to equitably achieve a representation of minorities in such socio-technical assemblages (Callon, Lascoumes, and Barthe [2001] 2009, 226). Minorities here also equate to laypeople, thus the question lies in forging ways in which the latter-who are still dependent on scientists and experts to help minimize the overflows of scientific and technological activity (i.e. the unforeseen problems) in their life-have a say. The acknowledgement of these problems has been actor-network theory's (ANT) and 
Science and Technology Studies' (STS) most relevant contribution over the past decade, and explicitly addressing ANT's purported de-politicized ontological project or STS's naive objectivity (Farías 2011, 366) has been a positive move. Recognizing that there are problems with the representation of minorities and laypeople in scientific practice inevitably leads, then, to the need for the type of inquiry which is able to trace, identify and follow such minorities when they enter into contact or collaboration with scientific or quasi-scientific interventions.

Outside the laboratory, many of the places where such interventions often happen are cities, and the objects of intervention are of an urban nature. What urban studies can contribute to this type of inquiry is its tradition of having been there, on the field, with the armies of laypeople and minorities who inhabit cities: unskilled migrants, lowincome residents, the homeless or the recently dispossessed, and so on. One group which experiences and understands better than most the built-in distance often created by scientific and governmental interventions between, on the one hand, formally sanctioned experts and, on the other, target populations, is slum dwellers or informal settlers. In various cities across the world, they sit outside the techno-scientific and administrative apparatus of housing and urban practice (consisting of architects, planners, engineers, municipal officials and many others) and are, or were, left to build an alternative city for themselves. This can occur, among other reasons, by the lack of access to regular housing markets, by sudden migratory influxes into urban contexts unprepared to integrate these influxes swiftly or by modernizing projects that deem entire parts of urban poor populations as ignorable and 'un-modernizable'. Whatever the combination of causes, after a period of time (whether years or decades after the initial settlement, made under conditions of invisibility, illegality and informality), housing and urban administrative apparatuses tend to notice the settlements and organize themselves to intervene on such extra-urban sites, as they then qualify them. The fundamental reasons for this second moment of integration vary too: it can aim to improve the housing and living conditions of slum dwellers and informal settlers when it is deemed possible; less benignly, it can aim to force these populations to 'come back' into the regular city, a disposition which often goes hand in hand with the wish to force illegal economies back (or for the first time) into regular markets; or, still more aggressively, to avoid violent insurrections which would perturb the broader social arrangements in a given city or country.

In any case, when scientists, engineers, planners, social activists, local politicians and others enroll themselves in particular initiatives to eradicate, curb, improve or rehabilitate slums and informal settlements, what tends to occur is a dissonant dialogue between the experts and the residents; that is, between those who produce the city according to more or less updated technoscientific paradigms and those who have produced it according to very idiosyncratic adaptations and variations of such paradigms. Such adaptations come, for instance, from established popular traditions (such as vernacular architectures); from the ad hoc learning of expert methods outside of formal education (as in the many cases worldwide of informal settlements built by workers of the construction industry); or finally by imagination or human ingenuity (but beware, the latter two tropes are often used by conformist observers to rationalize unequal regimes of precarity, with the usual argument going 'look at the wonders that people do when they are adapting to poverty').

There is a pressing need for a type of inquiry that seeks to explore the more or less dissonant interactions between the experts deployed (or self-deployed) to projects of intervention in poor built environments and the recipients of their attention. STS and ANT, having long studied the networks consisting of experts and the things that they surround themselves with, are 
well-equipped for this type of inquiry, as well as for the special attention needed to the object of dispute in cases of urban informality-the informal dwelling. The shanty, or shack, or whatever local designation it has, is often at the core of the problem and can be either identified as a cancer and stigmatized to justify clearance; more explicitly described as being in the way of the expansion of the formal city, or in the way of capital investment; or it can be opened to the possibility of being rehabilitated, with this option alternatively posited as either a cheaper way of solving the housing difficulties of the urban poor (as in slum upgrade projects) or as a way to grant the latter their right to stay put in the area. Such different truth regimes need always to be judged in relation to the political and historical context of individual cases, with a specific focus on the atmospheres of democracy in which professional expertise is developed and applied-in the sense that those atmospheres delimit the aims, methods and scope of interventions and interactions. But they need as well to be put into a broader analytical frame, into something akin to Latour's (2005) conceptualization of parliaments of multiple agencies (of things, technologies and people), in order to fully explore the enmeshment of scientific and quasi-scientific networks with what is considered to be the social-or, the city.

This paper looks at two different programs of intervention in informal settlements in Portugal in two different urban sites and from different periods (one from the 1970s and one from the very recent past), but belonging to a common genealogy of urban informality; a genealogy that operated according to specific Portuguese-speaking policy paradigms yet sharing plenty of contact points with global ones. ${ }^{1}$ This sets up a diachronic comparative gesture (Robinson 2011) in analyzing the different 'atmospheres of democracy' where interventions were developed. However, this paper also provides a somewhat counterintuitive sequence of techno-scientific moments in slum intervention, in the sense that it will show a path from more to less democratic arrangements over time-or, to use Callon, Lascoumes, and Barthe's ([2001] 2009) terms, from dialogical to delegative forms of democracy-which to an extent questions their implicit assumption that as societies get increasingly enmeshed with science and technology, so too are democratic instruments more and more generalized.

The first section shows the dialogically intense democratic experiments and interventions in 1970s Portugal with the SAAL (Serviço de Apoio Ambulatório Local) postrevolutionary housing program, which aimed at improving the conditions of existing shanty towns with assisted self-building and full cooperation between the state and informal settlers. In a way a prototypical form of technical democracy, the interventions from this period used perhaps modest but highly effective instruments for fruitful interactions. The second section discusses the watering down of residents' direct participation and representation in the IBC (Iniciativa Bairros Criticos) urban regeneration program in Lisbon during the late 2000 s, aimed at rehabilitating a favela-style informal settlement, and how people-to-people interaction was mostly substituted with computer software that represented all the dwellings to be intervened on, with the intention of constructing a hybrid research collective to make the rehabilitation of the non-standard urban fabric feasible. It entailed an interesting circular process of delegation and mediation, one crossing from residents to experts and back, through each house's fundamentals. However, the creation of such operational collective was also dependent on, and interacted with, forms of rationality that came from beyond the housing milieu and techno-science, namely, judicial rationality on property law. In both sections there is an explanatory tension between the need to acknowledge that structural forces (most notably urban capital and its invisible powers of enforcement) are at play in contemporary urban making, on the one hand, and the fact that promising dialogues or 
resistance are also possible, on the other. The latter include the way that potential futures (real or imagined) unleashed by democratic forms of engagement with laypeople can have a great permanence in people's minds and imaginations, with cherished ideas sometimes returning after four decades or more. The conclusion returns to these themes and to the question of how can techno-scientific sophistication be reconciled with effective urban democracy for the less powerful.

\section{The SAAL: technical brigades doing the revolution with residents}

For two years in post-revolutionary Portugal, between 1974 and 1976, a housing scheme captured the imagination and shaped the practice of thousands of residents in shanty towns in Lisbon and in Porto's inner-city tenement slums called ilhas, as well as of the architects, urban planners, legal advisers and other professionals who were involved in the program. The $S A A L-$ Serviço de Apoio Ambulatório Local (Mobile Service for Local Support)—was a program of assisted self-building or assisted design, which sought to respond to the severe housing shortages in the Lisbon and Porto metropolitan areas that Salazar's and Caetano's dictatorship had not been willing to address. Although housing had been one of the key arenas in which the construction of modern citizenship in Portugal under the dictatorship was forged-namely, through norms of social selectivity in the allocation criteria of the diminutive public housing stock (Nunes and Serra 2004; Pinto 2009)in effect the urban poor were led to settle in scattered informal or illegal settlements in the periphery or in over-dense inner-city slums (Salgueiro 1977; Bandeirinha 2007; Pinto 2013; Queirós 2013) (Figure 1).

In response to the eruption of popular movements across the country, including

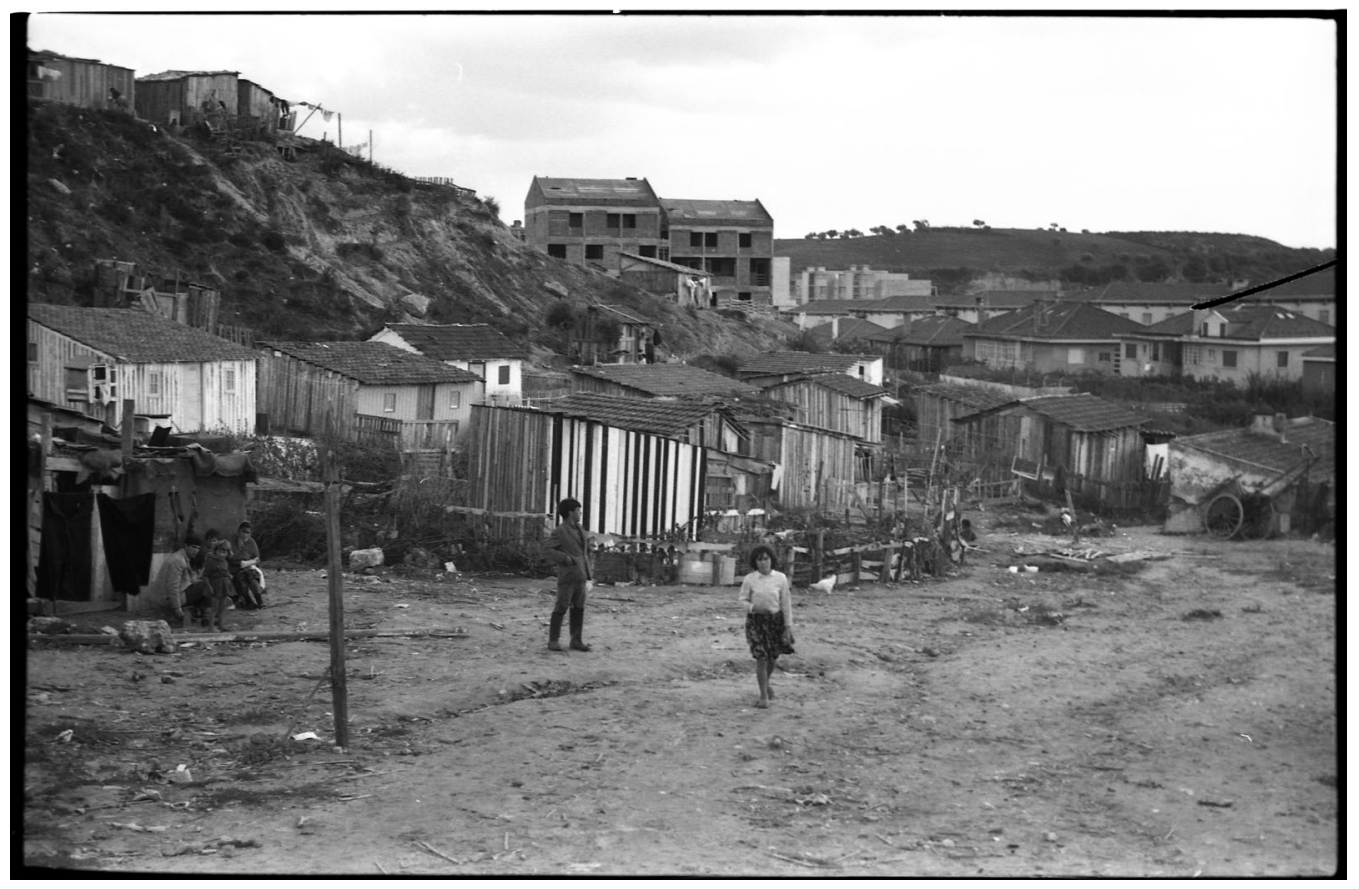

Figure 1 A small shanty town in Lisbon, c.1969 (Source: (C) Arnaldo Madureira, courtesy of the Lisbon Municipal Archive). 
those that demanded better life standards and 'decent houses for the people', the SAAL was enacted in August 1974, a mere three months after the coup d'état-turned-left-wing revolution. This was possible because the newly appointed Secretary of State for Housing and Urban Planning, architect and town planner Nuno Portas, along with a generation of architects, municipal officials, lawyers and academics (see Nunes and Serra 2004) had in the previous decade and a half prepared the way for the transformation of urban space that the existing revolutionary situation now allowed for. ${ }^{2}$ In accordance with the leftwing revolutionary zeitgeist, the program set up 'brigades of technical assistance' for each of the neighborhoods or sites to be intervened on. It demanded that the construction of the new neighborhoods was to be on the same sites as the existing ones (following the Portuguese derivative of the 'right to the city', the direito ao lugar ['the right to the place', which precluded displacement]); that, in building their house, residents were to receive aid in materials and 'technical advice' from the housing governmental agency Fundo de Fomento de Habitação (Housing Development Fund, from now on FFH) or from the freely elected City Councils; and that rent payments to partly cover costs were to be calculated according to income. Finally, it stated that the brigades of technical assistance (legal, architecture, financial accounting and construction) were not to substitute the populations: the government 'lent a hand' but those who were in need had to 'take initiative' (Ferreira 1987, 83). This was a call to the cooperative grassroots movements (Bandeirinha 2007; Pinto 2013) and to facilitate it, the scheme was organized at each site with a Residents' Committee responsible for relaying to the brigades exactly what was needed in terms of housing, land rights or social needs such as employment-for instance, in areas with high unemployment, projects sought to subcontract construction to unemployed residents organized in cooperatives (e.g. SAAL Curraleira Team 1984, 267).

\section{The brigades' work}

Respecting the principles of participatory social architecture-resident participation, user control and the self-help/self-built element taken from Turner and Fichter (1972)-interaction and exchange between experts' and laypeople's knowledge were thus intrinsic to the program's methodology. Architect Álvaro Siza-who was then involved in two projects in Porto, one at Bouça (see Rowe 1993, 294-295) and one at São Vítor-has recalled, 'dialogue [between architects and residents] was brutally honest, even conflictual' (Duarte 2014). This dialogue included exchanges about future house layouts (interior organization), morphology (density and street grid) and land tenure issues, all to be negotiated and designed in cooperation.

A fresh element in these discussions was participation of women. They were strongly involved in the design process, 'drawing the houses, telling [architects] where the bed would be, how to cross from one space to another' (Andrade 2014). In a report, the SAAL team for the Curraleira neighborhood explained how they had worked in this respect:

\footnotetext{
'Meetings were held with housewives in small groups of four where more detailed problems were solved, such as relations between kitchen, living room, and work space by changing partitions, doors, or equipment. Alternative finishes were also discussed and defined at these meetings. Field trips to other SAAL schemes in progress [...] were organized in this phase and to some housing component prefabrication plants as well.'

(SAAL Curraleira Team 1984, 268)
}

A second distinctive factor in the different discussions involved the differences in modes of interaction related to age. In Porto, architect Sérgio Fernandez used different architectural tools to show residents what their future homes would be like. These included models, but interestingly he recalled (Figure 2):

'Older residents didn't like looking at models, they said it didn't give them a clear picture of 


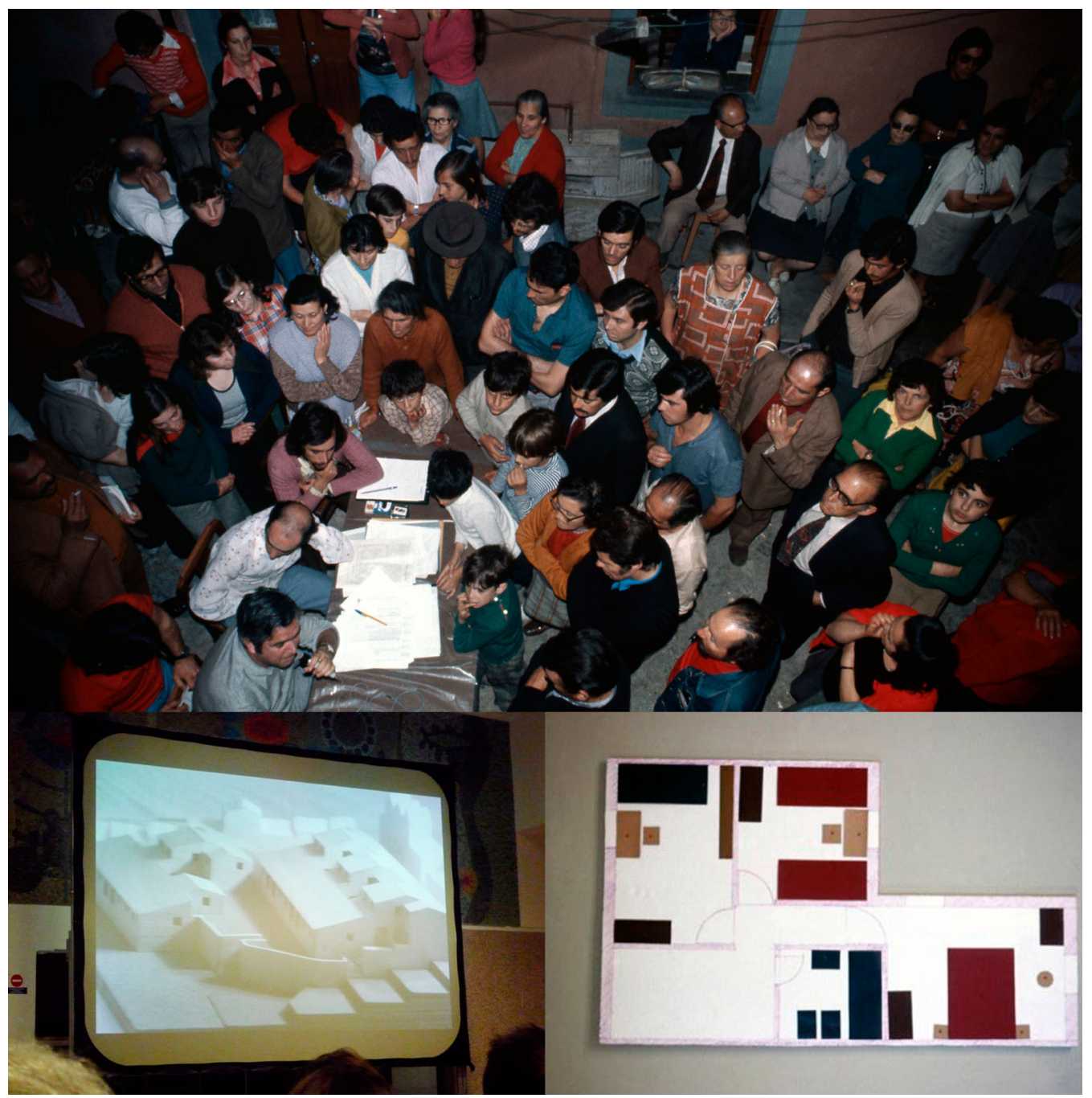

Figure 2 Discussion meeting between SAAL architects and residents, Algarve, 1976; model and house plan chart designed by architect Sérgio Fernandez to explain future homespaces to residents of Leal, Porto (Sources: (Top) (C) Alexandre Alves da Costa; (Bottom) (C) Sérgio Fernandez).

the final product, and would ask, "So where is the second story?" when it was there already. Younger residents liked models, but for the elder we brought in house plan diagrams with furniture signs, and these worked really well. With these they understood completely the potential of their future domestic spaces.' (SAAL Memory Meeting, Porto, 22

November 2014)

ANT literature on the cognitive aspect of architectural representation has shown that representation via models has become a staple of architectural practice (Yaneva 2005). Here it was as if lay cognition of architecture had to rely on the already tried and tested two-dimensional technologies of architectural representation to convert abstract representations of space into self-visualizations of their future lived space, even if it meant foregoing a three-dimensional technology. ${ }^{3}$

These episodes are illustrative of the methodology of interaction. What was substantively 
and intensely discussed, debated or negotiated varied according to the political and urban circumstances at each site. One of the most common dichotomies was between low- and medium-rise solutions, sometimes associated with the options of using variations of vernacular or late modernist housing languages. So, for instance, in Lagos' Meia-Praia scheme, architect José Veloso proposed a design which was able to reflect as much as possible, in concrete, the positive elements of fishermen's dwellings in canes or used industrial materials. At Bouça and especially at São Vitor, Siza designed a careful approximation to the ilhas' morphology with a view to preserving the existing sociability, but of course with each house now having its own toilet instead of sharing one at the end of an inner patio (Grande 2010, 21). In Lisbon, on the other hand, head architect Raúl Hestnes Ferreira and brigade architect Vicente Bravo Ferreira (part of a larger team) designed a late modernist medium-rise solution in Quinta $\mathrm{da}$ Calçada, with its back to the ring road Segunda Circular and a system of inner squares to address the issue of street life. The various experiments were in dialogue with the more progressive and participatory architecture of the time, which often played with architectural evolution and adaptation (e.g. Habraken's [1972] Supports). Architect Francisco Silva Dias, for instance, designed the Alto do Moínho neighborhood next to Bairro do Zambujal in the Oeiras municipality (today sitting next to an Ikea store) with a scheme that comprised self-built evolution, enabling residents to add rooms and other spaces over time (Bandeirinha 2007, 385). He recalls that in the following years, 'residents would call me to ask for permission to build a new room in such or such way' (pers. comm., architect Filipa Serpa).

A second recurrent issue debated by brigades' members, residents and the $\mathrm{FFH}$ as competing technological frames (Aibar and Bijker 1997) was the option between selfbuilding and professional contracting of construction. In some places such as the Relvinha neighborhood in Coimbra's periphery, residents wanted to build the houses themselves, 'to feel they were ours' (Baía 2012, 125). In more politicized areas such as Lisbon's industrial belt, where the Portuguese Communist Party or Trotskyist parties such as the PCTP-MRPP held considerable influence, residents complained about the 'double exploitation' of having to work during the day in their usual jobs and then self-build their houses in the evenings, or well into the night (SAAL 1976, 119; Bandeirinha 2007, 141). Curiously, however, there was no overall winning frame in the sense that at each site the population, in dialogue with the FFH and the brigades, opted for what they decided was more convenient. This was an early example of something that could be taken as indecision or temporization, but that Callon, Lascoumes, and Barthe ([2001] 2009, 191) appropriately call 'measured action'.

Legally, too, important advances were made regarding land property arrangements. In Outurela, Oeiras after the public expropriation of land to construct the 18 de Maio neighborhood, the sub-divided individual plots became collective cooperative property of the Residents' Association, which today is still responsible for allocating houses (e.g. when an elder occupier dies) to its most-inneed members. Such implementation of a commons was aimed at avoiding future speculative activity with the land that had been expropriated with the sole purpose of guaranteeing housing for the poor.

These and other matters of concern all boiled down to one key issue, the speed of implementation. In fact, the different options could only be relevant elements for the new neighborhoods if the latter were to exist at all. From the start, projects were envisaged to be built quickly, that is, within an approximate timetable of three years, to avoid despair over 'failed promises' and 'unfulfilled expectations'. ${ }^{4}$ One strategy to prevent discouragement was to start construction early on, with whatever means available, instead of waiting for FFH's bureaucratic decisions to release the previously negotiated funding (Baía 2012, 
126). And all these things—dialogues between slum dwellers and architects, options regarding housing density or architectural style, construction modalities, expropriation and collective property, urgency-were set amongst the revolutionary atmosphere, in which the citizenship status of slum dwellers (hitherto considered neglectable) and the way the city was produced (a capitalist-corporate mode of production) were to be radically altered.

\section{A parliament for the recently enfranchised}

The Residents General Assembly at Porto's Palácio de Cristal on 5 April 1975 was one of the pinnacles of this atmosphere of dialogical democracy; it was a hybrid forum where all the expectations and tensions were raw and visible. The expectations and a heightened sense of democratic intensity came from, among others, the fact that after 48 years of patriarchal dictatorship, women were voting on matters of concern to their household, indeed, were leading the way (Figure 3(a)). The tensions were related to the strong sense of urgency in getting construction underway or houses completed because people were starting to realize the revolution period was in danger of coming to an end-as it did, after the failed Communist coup on 25 November 1975 . Hence very rationally, laypeople wanted to replicate the customary politics of expert or governmental faits accomplis, but for once to their benefit: they wanted to see houses on the ground before the program was reversed. They thus complained about slow implementation: in the balcony above the representatives of each of the local associations, a banner demanded 'Down with the parasites at FFH' (Figure 3(b)).

\section{What did social architecture during the revolution achieve?}

If we analyze the SAAL with Callon, Lascoumes, and Barthe's ([2001] 2009, 160) parameters for dialogical procedures, we can argue the program's methodologies and expert-laypeople interactions involved a high degree of intensity (translation for the involvement of laypeople in the exploration of possible worlds and the concern for the composition of a collective); as well as of diversity (translation for the diversity, independence and representativity of laypeople in the established action groups); but that, regarding its quality (related to the seriousness and continuity of the voice of laypeople), it oscillated between an undeniable 'seriousness of voice' and an unfortunately curtailed 'continuity of voice' owing to the program's dismantlement. ${ }^{5}$

With hindsight, Álvaro Siza proposed, with semiotic precision, that this process was intense but that it still involved a form of mediation: 'Commitment to residents did not mean to directly assume all their aspirations, but rather to be permanently aware of being in the process of representing their interests through a particular form of representation, which in this case was architecture' (Siza in Bandeirinha 2007, 254). In other words, although architecture as a scientific discipline did not supersede laypeople's aspirations or worldviews, it still formatted them. Dialogue was instituted but circumscribed within discrete disciplinary boundaries. In addition, the product of the exceptional circumstances of interaction, over time, became more a currency in experts' knowledge and careers (i.e. an experience which they could translate to buildings designed later on, in more classic situations between architect and client) than a basis for the continuation of laypeople's emancipation. The Progressive Era was coming to a halt.

\section{The IBC: computerizing the built environment}

We fast forward to the recent past. After the SAAL, Portuguese housing policy was reoriented to general supply through home ownership. After a second explosion of informal settlements in the 1980s, due to the 


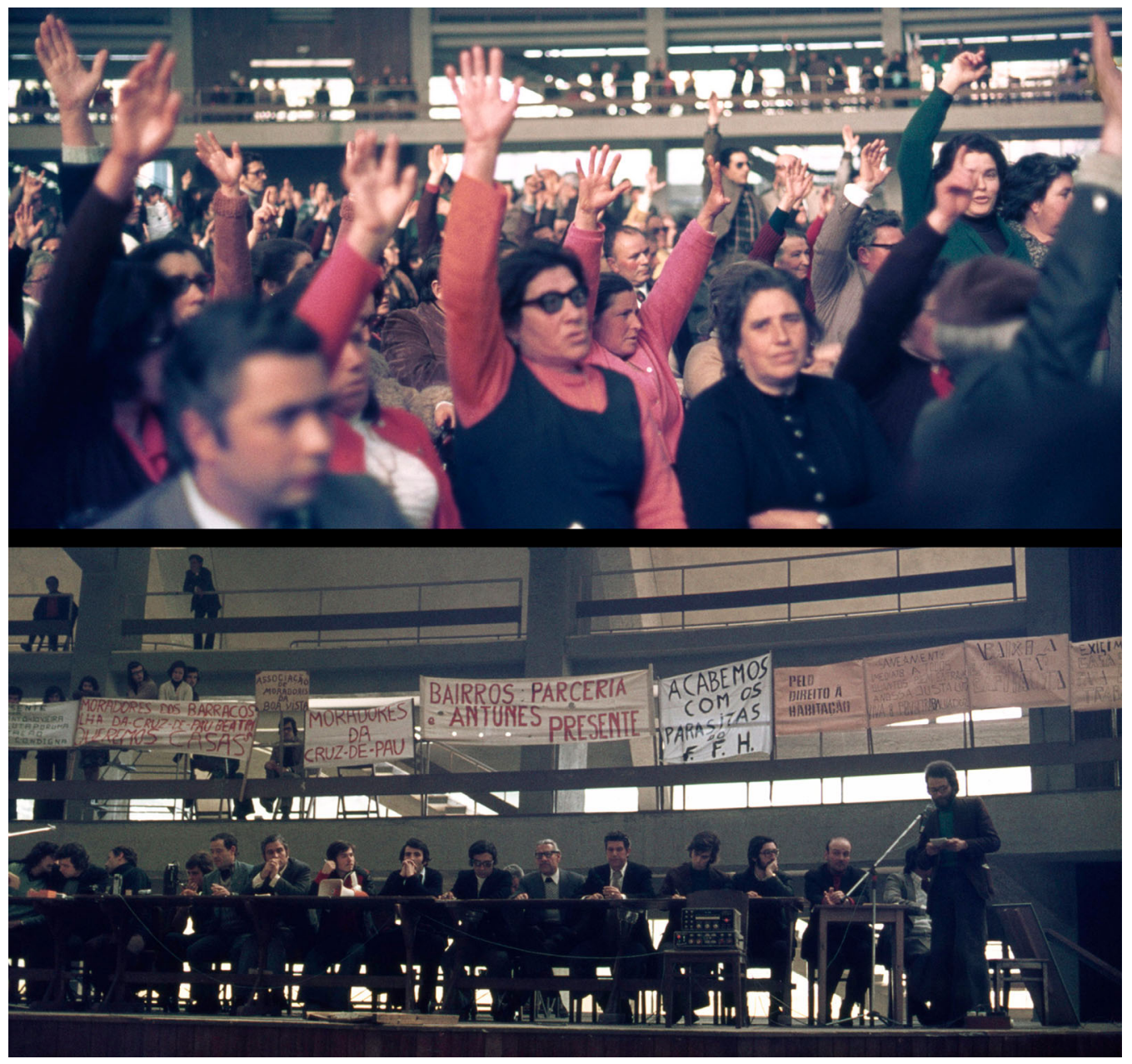

Figure 3 A parliament for the recently enfranchised: the SAAL meeting at Palácio de Cristal, Porto, 5 April 1975. Top, women vote. Bottom, the representatives of each local association (Source: (C) Alexandre Alves da Costa).

incoming migration of poor postcolonial migrants who were priced out of the housing market and unable to access public housing (comprised of a meager 100,000 units countrywide), a comprehensive program of slum clearance and rehousing in the Lisbon and Porto Metropolitan Areas, the PER, was enacted in 1993 (see Cachado 2013; Ascensão 2015). ${ }^{6}$ Coming at the tail end of the PER, the experimental scheme Iniciativa Bairros Críticos (Critical Neighborhoods Initiative, from now on IBC) sought a departure from the PER's top-down approach and in a way resumed the intention of a participatory politics applied to housing (Ascensão 2013, 165-166). It focused on three areas deemed 'critical', one of which is the favela-style settlement Cova da Moura in the municipality of Amadora near Lisbon, a much studied settlement with a majority of African immigrants (see also Beja-Horta 2006). Partly inspired by the Favela-Bairro program in Brazil and partly by European urban regeneration programs (again we see the links to the different branches in a complex genealogy), the IBC at Cova da Moura instituted a holistic approach to the regeneration of the 
neighborhood. The most important development strands focused on land legal regularization, on the rehabilitation of the built environment, on youth employment and participation, on the reinforcement of the local economy and on supporting pre-existing grassroots associations.

Regarding the second of these strands, on which this section focuses, the rehabilitation of the built environment here meant a will to refurbish or rehabilitate all the dwellings in the neighborhood, instead of clearing the site and building a new housing estate. Underpinning this will to rehabilitate was the wish to materially grant the population its right to the place (i.e. the right to stay put and not be displaced), which was also linked to the idea of a recognition by the state of the culture and knowledge of the population who had built the neighborhood with informal techniques and collective effort over the previous 40 years. This was a sophisticated way of assuming that there existed a proxy morphological and architectural identity in the neighborhood's urban layout and the dwellings' architectural configurations, one that needed to be preserved. What is commonplace in the regeneration schemes of historic centers-upgrading urban and habitability conditions while maintaining the genius loci-was here applied to an informal settlement with substandard dwellings.

This was an interesting and somewhat counterintuitive approach, in the sense that it implied that experts recognized that a significant part of the buildings-which had not been built according to any architectural or engineering by-laws-were nonetheless structurally sound enough to withstand major improvement works. Set within a multicultural urban politics aimed at fully integrating the aspirations and cosmologies of a population of postcolonial immigrants, it was a nod to informal contractors' and residents' expertise in building, over the previous 40 years. Such a refreshing attitude towards the informal city was particularly exceptional if we consider that, for the past two or three decades, the issue of buildings not being 'structurally sound' had been one of the main rhetorical tricks deployed in urban regeneration projects worldwide to justify demolition and displacement of residents (e.g. Jacobs, Cairns, and Strebel 2007, 624; Lees 2014, 923, 929). At Cova da Moura, at least initially, such rhetoric was disavowed. ${ }^{7}$

The key issue thus concerned the actual possibility of these dwellings being rehabilitated. It asked whether they were really structurally sound and could be upgraded, for instance, with pinpoint interventions at gas joints, water or sewage connections, lighting and so on; with small architectural acupuncture such as opening windows in closed façades, thus improving light and air conditions inside the dwellings; or with the demolition of adjoining houses that might immediately improve the habitability of several others. Establishing the veracity of these 'uncertain facts' (Callon, Lascoumes, and Barthe [2001] 2009) was to be answered by an independent assessment of the built environment, to be carried out by the National Laboratory of Civil Engineering (Laboratório Nacional de Engenharia Civil, from now on LNEC). The 'official science' of housing and engineering had been summoned to arbitrate this urban uncertainty.

Because of time constraints, instead of a thorough structural analysis with ultrasounds and other robust methods, the LNEC devised a methodology of visual assessment of all the 1617 surveyed dwellings units in the neighborhood, based on a 20 minute visit of each one. These visits focused on the individual dwelling's rehabilitation needs as well as its relation to the adjoining dwellings. Such individual characteristics came both from the 'naked-eye' observations by the engineers and architects inside the houses and from a list of recurrent anomalies they had to check and tick the corresponding boxes in the individual file (see in detail, Ascensão 2013, 166-173). ${ }^{8}$ These elements were then input into an individual database file and an algorithm rendered them into overall scores that suggested the 
need for light, average or comprehensive rehabilitation the dwelling required per se and in relation to others. Finally, this was graphically represented in different maps of the neighborhood, one for each of the main characteristics to be assessed (e.g. 'walls/ bays without fire resistance'; 'air and light in inhabited spaces'; etc.; see more, LNEC 2008) (Figure 4).

What does the computer algorithm generate?

The computer assembles the dwellings and gives them representation in a new collective, which is the neighborhood in map form. These maps, then, become the assembly of all dwellings - with their families, dramas, problems and joys related in each case to unique, non-standard, material houses-into one coherent whole. The machine enabled making uniform what was utterly nonuniform to begin with, in a case of 'distributed intelligence' (Callon, Lascoumes, and Barthe [2001] 2009, 57) between human observation and the aptitude of the instruments used for the elaboration of knowledge. This was a positive trait, given it would enable operationalization of a particularly complex urban fabric by the architectural and engineering team that would be responsible for the detailed urban design of the site.

Dialogue and participation was a far more difficult process. The top-down tradition of urban planning in Portugal (Cardoso and Breda-Vázquez 2007) was visible in some of the public participation meetings at the neighborhood, with politicians from the central government, the mayor and members of the project team making expositions on how the process would proceed but failing to integrate people's complaints

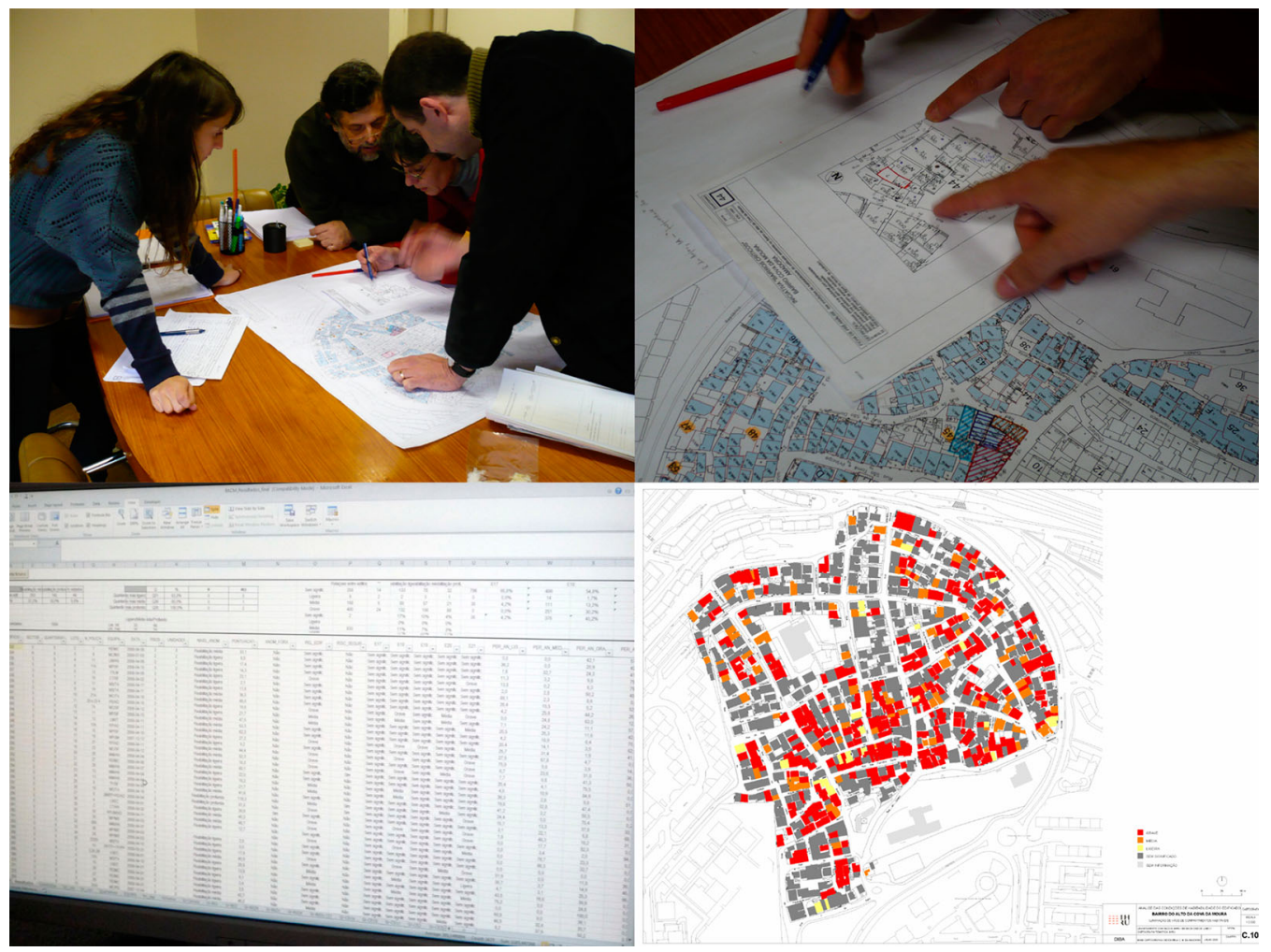

Figure 4 Each house laboratorized, one neighborhood represented: LNEC's visual assessment methodology and computer software assembles data from all dwellings into a coherent form (Source: (C) Author). 
and anxieties into the policy process (research observation, public participation meetings, February and July 2008). There was transparency in disclosing information but only token participation, as noted by the most vocal residents.

Essentially, the representation of peoplethat is, of each family - was made through the characteristics of their dwellings in a diagram rather than through any type of human-tohuman dialogue. The entities that were represented were the dwellings, and the program's later configurations would respond only to those. Such a situation belongs to the almost imperceptible shifts in the nature of social operations in late modernity whereby the agency of 'things' is increasingly enmeshed with, and sometimes substitutes, the agency of 'people' in policy and implementation; but, it is also an example of Callon, Lascoumes, and Barthe's ([2001] 2009, 106) cycles of translation and delegation in scientific activity, from reality to research collective and back to reality. However, in practical terms such type of mediated representation made clear that the ultimate objective it was designed for-the rehabilitation of the dwellings and of the neighborhood in general-was entangled with a paradox hard to undo.

The evaluation results exposed a very fragile situation regarding many buildings, and the maps tellingly show that to grant most families a material amelioration of their dwellings, some of the more dense clusters of houses had to be broken up, with those in worst conditions demolished to make space for improvements. As such, a part of the population had to be displaced (Ascensão 2013, 174-175). This was the closest to certain and certified knowledge the experts had reached. The research collective had analyzed the dwellings as proxy indicators of social reality and in getting back to the latter (the neighborhood's residents) it essentially informed them that a possible solution would rationally have to involve the neighborhood's re-configuration in terms of urban fabric, and thus also in terms of social composition. As a micro-political problem, it could have been solved by managing to get those who wanted out of the neighborhood (into new-built apartments in the vicinities or, should they opt to, other places) as quickly as possible in order to free space for the rehabilitation of those who preferred to remain. Indeed, this was envisioned as a possible course of action by the project team (interview, 2008). The fine-tuning would have been difficult and susceptible to some injustices, but possible.

But instead, it was solved by the other way of solving paradoxes, which is to bury them under a new, big fact. Such a new, big fact came from the outcome of the international competition to select the architectural and engineering team responsible for the detailed design and building of the new neighborhood. There were two main entrants, both of which had previously been engaged in studies in the neighborhood. The first one was a consortium of university specialists (from geography, architecture and other disciplines), which planned to implement the rehabilitation approach but with a more robust consultation than previously managed, including a survey of all the households, 'visioning workshops' and walking interviews with selected residents (Raposo and Malheiros 2010). The second one was a private architectural office, close to the mayor's office, which instead proposed a more directive clearance and medium-rise solution, that is, it proposed to avoid all the complications of consultation or participation at the micro-level and implement an abstract plan from scratch (Cunha 2010). Each proposal was clearly located within a different branch in the broad genealogy of intervention in informal settlements mentioned in the introduction to this paper. The winner was the latter, which meant the dismissal of rehabilitation and reversion into a new-built solution, with clearance of all the existing dwellings. Within such a solution, there was now a clear loss of 'parliament representation' for the dwellings, and indirectly this also meant a loss of parliament 
representation for their families, memories and expertise that the original solution was devised to respect. In the original plan, the computer software introduced a type of technical rationality that tends to override political considerations-algorithms produce values independently of judgement. However, by creating a representation for the dwellings, a supposedly 'apolitical' technological procedure de facto guaranteed a techno-political representation for the families, in which the dwelling and the family household were entangled in one single entity. This loop was particularly constructive because it seemed to be able to prevent a scheme entirely imposed from the top. By contrast, in the winning proposal the diagnosis work and the technological mediation described above would be wasted and a straightforward top-down solution implemented. Furthermore, the bigger risk for families was that this loss of representation could mean (as it still can) that they will not get to stay in the new buildings but rather be displaced to other sites, further away, as was common in the previous PER program.

All along this process, the first strand concerning land regularization was not achieved because the family who owns the landwhich was neglected and abandoned when the settlement began yet never expropriated-successfully made every legal injunction possible and rejected all negotiated solutions with the municipal authorities and the central government, in order to be able to cash in on a property that has since seen its value appreciate due to its excellent location on top of a hill as well as its proximity to urban infrastructure, such as the nearby Damaia train station. Such 'speculation by absence' (interview, 2008) has been tolerated by the judicial system and failed to be confronted by the different governments with powers to expropriate the land (which could then be reverted to the population through forms of collective or cooperative property such as those of the SAAL), and this led to a critical impasse. ${ }^{9}$
The final nail in the process came at the very end of its first stage. The IBC had used project funding from EEA Grants to cover the initial diagnosis and action framework design. For the second stage concerning housing rehabilitation to be fully implemented at Cova da Moura, a new cycle of funding would be needed, most likely to come from the state budget. However, with the abrupt cuts in public expenditure in all sectors of the economy following the Structural Adjustment Program Portugal signed with the IMF (International Monetary Fund), the ECB (European Central Bank) and the European Union in May 2011, the IBC was left hanging without any resource pool to draw from. The program was suspended and later abandoned, yet another victim of European austerity policies.

What can be argued about this course of events is that after the delegation to a research collective and the reduction of social reality into measurable parameters, the final moment consisting of the extension of the research findings back to reality encountered a problem that came from beyond the planned procedures of technical democracy yet proved to be stronger and superseded them. First, the architectural competition re-configured the original issue at stake, which the experts had been summoned to arbitrate-whether rehabilitation was possible, and what would it entail for each individual dwelling and household-and was able to revert it into a broader binary decision on how to intervene on the site (either rehabilitate or clear and re-build). It thus re-opened the door for an option that was not there at the beginning of the process, indeed the one option that the process had been initiated to avoid. Second, such a regression to the typical adversarial options regarding contexts of urban informality, and the re-emergence of the possibility of clearance and displacement, inexistent at the start of the process, was particularly advantageous for the landowners, who wished to develop the site for middleclass residential development rather than for 
the low-income groups who inhabit it at present. To achieve it, they enrolled a different set of rationality forms (legal and judicial rationalities, particularly those pertaining to property law within a market society) to defend their case, and did so successfully.

So a perceived failure of technical democracy in this case was not truly caused by its constitutive elements nor by technocratic rationality failing to institute more dialogical procedures (which were visibly absent but could still be introduced, as the first entrant in the competition proposed), but rather by the interrelationship between the four things that happened in succession: the technical assessment of buildings (which came up with a new matter of concern); the architectural competition (which redefined the issue at stake and enabled the re-emergence of the option the whole process was meant to avoid); the judicialization of property issues in combination with an accessary local authority (the description of this relationship is not in the remit of this paper); and finally an abrupt cut in public expenditures on housing (which meant that the current status quo will stay). Each of these things was stronger than the former and the potential of technical democracy to address the overflows coming from the rehabilitation experiment was overweighed by these other elements.

\section{Conclusion}

These two experiments show that urban histories and state or scientific interventions in informal settlements at various locales do not necessarily follow a linear development, indeed that they can take regressive turns at various junctures. The two cases are especially illustrative of the tension between technical democracy's tenets and working frameworks (dialogical or delegative), on the one hand, and the workings of urban capital formations, on the other. In 1970s Portugal, the SAAL constituted a progressive housing program, which instituted participatory democracy and a collaborative framework between the state, experts and target populations to solve an urgent problem, but it went against the capitalist status quo (particularly regarding urban land property) and was halted. In 2000s Lisbon, the IBC, despite the absence of a full-on dialogue between residents and experts, was enacted within a benign technocratic multicultural atmosphere under which the experiment of 'representing-residents-through-their-house-conditions' was attempted, but austerity-related cuts and, again, pressures from urban capital, made it derail and fail to reach conclusion.

In light of these cases, Callon, Lascoumes, and Barthe's ([2001] 2009) hopeful tone regarding the potential of technical democracy needs to be weighed against actually existing outcomes of proto- or full technical democracy initiatives-especially in those arenas where the power imbalances between experts and laypeople are extreme (and intervention on slums is one such case). The two cases presented suggest that at least in the urban arena the potential of technical democracy tends to interrelate with, or come up against, other elements, including urban capital's particular type of agency. Mechanisms of urban capital accumulation, although not necessarily a pervasive hidden force which supersedes all things, nonetheless tend to minutely disrupt, sabotage, suspend or cancel actually existing initiatives of cogent expert-laypeople interaction and general social emancipation. For spatial Marxism, the particular feature of cities and urban space is that they are where capital formations, ethereal until then, 'land' and become palpable (e.g. Harvey 2001; Lefebvre 2003). In the process-whether we take this standpoint as the final and exclusive explanation for the urban process or instead as an important one among a networked constellation of other forces, maneuvers and strategies-we factually know that real-estate funds, developers and so on can, and often do, tweak, subvert or bypass regulatory frameworks to their advantage (including using judicial, architectural and planning 
technicalities as instruments for their objectives, as we have seen). A by-product of this situation is that the collaborative efforts and multiple agencies assembled around the potential of technical democracy can be brushed aside or crushed (see also Farías, this issue). This is one of the main evidentiary points this paper has tried to point to. However, becoming aware of this fact does not mean, in any way, to suggest that the potentials of technical democracy are irrelevant (quite the contrary), only that they come up against adversarial elements and need to be prepared to face them (see also Blok, this issue).

An example of the strength of urban capital as counter to technical democracy relates to the cases presented comes from one of SAAL's sites, Siza's Bouça in Porto. In the 1970s, only its first phase was completed. The second phase was finished in 2006, but it essentially paved the way for the gentrification of the neighborhood, now being bought by Porto's young creative elite because of its excellent location and the appeal of inhabiting a house designed by a celebrated architect. In an open talk meeting in 2014 between the architects who worked for the SAAL and the target populations, Siza was confronted with the issue. He attempted to disarm it and replied that his intention in the original plan was to build an 'inter-classist and inter-generational neighborhood, as the whole city should be' (Duarte 2014), but the tension related to gentrification was visible. In particular, in the past few years of acute economic crisis in Portugal (2011-present), a strong sense of nostalgia for the ideas and practices the SAAL encapsulated emerged in the architectural and planning professions as well as in public opinion in general. Chief among these ideas is the nostalgia for participation, for a dialogical and committed way of producing urban space where the people (everyone) can live and work.

The current context is different; more technologically sophisticated than before, as the IBC shows, but a significant part of the question remains: what is needed to reconcile expert knowledge and technological sophistication in initiatives of slum rehabilitation or regeneration with urban democracy for the less empowered, in Portugal and elsewhere? I risk the answer that what is needed, at all times, is a political atmosphere where the urban poor are taken as citizens or voters to which policy and initiatives on the ground need to respond, instead of numbers or details in broader strategies of state legitimization, reconfiguration or sovereignty coupled with urban capital accumulation; in the latter, no matter how righteous the beginnings, the urban poor tend to end up as neglected entities in the network. Technical democracy is only such a thing (and not simply technocracy) if laypeople's wishes are integrated in procedures and operations. Regardless of how modest the tools for such integration are-such as SAAL architects' cardboard house layouts to explain and interact with residents-what matters is that they are wholeheartedly integrated. As Callon, Lascoumes, and Barthe ([2001] 2009, 248) identify with precision: 'What is essential for ordinary citizens and laypersons in dialogic democracy is not participating, but weighing up and contributing.' This is easier stated than found, but it is a point from which to depart if we are to recognize that the tenets of dialogic technical democracy are not only obvious but much needed in any future arrangements for a truly just cosmopolitics.

Empirical or theoretical advances starting from this point dovetail with the discussion Brenner, Madden, and Wachsmuth (2011) and Farías (2011) have initiated on the politics of urban assemblages and critical urban theory, a discussion which can be productive if both sides seek points of convergence. Put telegraphically, such a discussion can move forward if the latter acknowledge that urban capital formations have a specific type of agency (as put forward above) and thus need to be factored in a particular way in any explanation, or that indeed, urban assemblage theory perhaps needs to specify further the historical geographies of power in urban assemblages (rather than merely emphasizing 
an irreversible ontological shift that will dispense with them); but also if the former understand that there is nothing inherently uncritical in ANT's or STS's symmetrical projects, nor that most of those or of assemblage-inspired analytical efforts are based on decontextualized standpoints that ignore 'actually existing social relations and institutional arrangements' (Brenner, Madden, and Wachsmuth 2011, 225). This paper tried to work through such a potential convergence by being attentive to both the institutional arrangements and the networked procedures and operations that make up existing interventions.

\section{Acknowledgements}

The author would like to thank lgnacio Farías and Anders Blok for their perceptive comments on an earlier version of this paper.

\section{Disclosure statement}

No potential conflict of interest was reported by the author.

\section{Funding}

This work was supported by a postdoctoral grant from the Fundação para a Ciência e a Tecnologia [grant number SFRH/BPD/95806/2013].

\section{Notes}

1 From modernist models of slum clearance and tabula rasa new-built to progressive assisted self-building, or finally sophisticated in situ rehabilitation models, the history of intervention in Lisbon's shanty towns over the past five decades has several continuities regarding intervention models, rhetoric and broad political objectives, all of which are in dialogue with similar situations in other cities across the world. The country's and the city's particularity, related to its semi-peripheral geographical location, is that such policy and intervention dialogues are sometimes developed within urban paradigms associated with cities in the Global North, but at other times developed within those associated with cities in the Global South. Furthermore, these shifting urban dialogues are also situated within the colonialpostcolonial transitions of cities such as Maputo, Mozambique; Luanda, Angola (both with a catalogue of UN Habitat assisted slum upgrade projects); and even, to an extent, Rio de Janeiro, Brazil. There is thus a need for a careful analysis of such translocal policy assemblages in their relation to broad, longue durée political histories, if we are to minimally understand what is, or was, going on at different sites in different time periods. See more, Ascensão (2013), Raposo and Oppenheimer (2007) and Valladares (2006).

2 This preparation included the subversion of technical economic parameters of conservative housing policy Casas Económicas (Affordable Houses) to make way for more democratic urban forms, materialized in the planning and architectural construction of grand ensembles of modernist buildings such as Olivais Sul (Nunes 2007).

3 Remember, for elderly people in 1970s Portugal an architectural model still had an element of novelty. We can speculatively transport such a distinction to the present if we think about an elderly layperson today perhaps preferring to look at a model instead of at a more detailed AutoCAD rendering.

4 This was in line with Turner and Fichter's (1972) findings from Latin America that land regularization and self-built housing projects need to be implemented within a maximum time span of three years.

5 By 1976, the program's exemplification of direct democracy, which had served to legitimize the new democratic state, was considered by many a threat for the country, now exiting its revolutionary period and entering a period of normalization, towards a market society. Any experiences that could be seen as alternatives to 'normal', parliamentary and representative democracy were swiftly eliminated. Bandeirinha (2007, 175-218) describes this winding down in great detail: the responsibility of implementation was passed from the $\mathrm{FFH}$ to the different municipalities where sites were located; the latter were much more permeable to private interests from corporate landowners or to top-down ideological diktats regarding the irrevocability of private property than the circumscribed and coherent SAAL team at FFH (the Porto offices of which were bombed by right-wing militants on 14 January 1976), which was highly flexible regarding the different solutions for each site, provided residents' wishes were fully integrated into them. The SAAL's dismantlement can be summarized by the fact that only 7000 of the planned 40,000 dwellings were ever completed. 
6 A situation which continues and is well illustrated for instance by the latest official figures for the 1987-2011 period, which show an overwhelming $73 \%$ of all of central government's housing-related funding dedicated to homeowners' mortgage subsidies and only $14 \%$ to public housing development (IHRU 2015, 4). This indicates a deep financialization of the housing sector.

7 As I have pointed out (Ascensão 2013, 166), this was not a slum upgrade implemented in order to save money on the possible costs of new-built apartments on the same site; rehabilitating these dwellings was estimated to cost around $120 \%$ of the average 'technical cost' of an apartment in a new-built estate (interview, 2008).

8 The methodology is presented in Vilhena, Pedro, and Paiva (201 1), and is in dialogue with other European research on condition assessment of buildings (e.g. Straub 2009).

9 At this point we must track back to note that the population's decades-long demand for in situ rehabilitation (and infrastructure provision in the interim) was leveraged by successive trade-offs with local politicians (Beja-Horta 2006, 276). However, when push came to shove the previous mayor of Amadora-who was in office from 1997 to 2013 and who in 2004 was suspected by judicial authorities of receiving illegal payments from realestate developers (the case was dropped in 2013)swung to the landowner's side.

\section{References}

Aibar, E., and W. Bijker. 1997. "Constructing a City: The Cerdá Plan for the Extension of Barcelona." Science, Technology, \& Human Values 22 (1): 3-30.

Andrade, S. 2014. "Melhorar a vida e a cidade, quarto a quarto", in Público 31/10/2014.

Ascensão, E. 2013. "Following Engineers and Architects Through Slums: The Technoscience of Slum Intervention in the Portuguese-Speaking Landscape." Análise Social 206: 154-180.

Ascensão, E. 2015. "Slum Gentrification in Lisbon, Portugal: Displacement and the Imagined Futures of an Informal Settlement." In Global Gentrifications: Uneven Development and Displacement, edited by L. Lees, H. B. Shin and E. López-Morales, 37-58. Bristol: Policy Press.

Baía, J. 2012. SAAL e Autoconstrução em Coimbra: Memórias dos Moradores do Bairro da Relvinha 1954-1976. Castro Verde: 100 Luz.

Bandeirinha, J. A. 2007. O Processo SAAL e a Arquitectura no 25 de Abril de 1974. Coimbra: Imprensa da Universidade.

Beja-Horta, A. P. 2006. "Places of Resistance: Power, Spatial Discourses and Migrant Grassroots
Organizing in the Periphery of Lisbon." City 10 (3): 269-285.

Brenner, N., D. J. Madden, and D. Wachsmuth. 2011.

"Assemblage Urbanism and the Challenges of Critical Urban Theory." City 15 (2): 225-240.

Cachado, R. A. 2013. "O Programa Especial de Realojamento: Ambiente Histórico, Político e Social." Análise Social 206: 134-152.

Callon, M., P. Lascoumes, and Y. Barthe. [2001] 2009. Acting in an Uncertain World: An Essay on Technical Democracy. Cambridge, MA: MIT Press.

Cardoso, R., and I. Breda-Vázquez. 2007. "Social Justice as a Guide to Planning Theory and Practice: Analyzing the Portuguese Planning System." International Journal of Urban and Regional Research 31 (2): 384-400.

Cunha, V. 2010. Concurso Público Internacional Para a Aquisição de Serviços de Elaboração do Plano de Pormenor da Cova da Moura: Proposta. Lisboa: Vasco da Cunha Estudos e Projectos.

Duarte, M. 2014. "As discussões eram de uma sinceridade absoluta, muitas vezes conflituosa", in Público $10 / 11 / 2014$.

Farías, I. 2011. "The Politics of Urban Assemblages." City 15 (3-4): 365-374.

Ferreira, A. F. 1987. Por uma Nova Política de Habitação. Porto: Afrontamento.

Grande, N. 2010. "Revolución Y Regeneración Urbana. El Bairro da Bouça de Álvaro Siza: Entre el Clavel y el Bolígrafo." La Ciudad Viva 3: 20-26.

Habraken, N. J. 1972. Supports: An Alternative to Mass Housing. London: Architectural Press.

Harvey, D. 2001. Spaces of Capital: Towards a Critical Geography. London: Routledge.

IHRU. 2015. 25 Anos de Esforço do Orçamento de Estado com a Habitação. Lisboa: IHRU.

Jacobs, J. M., S. Cairns, and I. Strebel. 2007. "'A Tall Storey... but, a Fact Just the Same': The Red Road HighRise as a Black Box." Urban Studies 44 (3): 609-629.

Latour, B. 2005. "From Realpolitik to Dingpolitik." In Making Things Public: Atmospheres of Democracy, edited by B. Latour and P. Weibel, 14-41. Cambridge, MA: MIT Press.

Lees, L. 2014. "The Urban Injustices of new Labour's 'New Urban Renewal': The Case of the Aylesbury Estate in London." Antipode 46 (4): 921 -947.

Lefebvre, H. [1979] 2003. The Urban Revolution. Minneapolis: University of Minnesota Press.

LNEC. 2008. Análise das Condições de Habitabilidade do Edificado no Bairro do Alto da Cova da Moura. LNEC Report 366/2008. Lisboa: LNEC.

Nunes, J. P. 2007. À Escala Humana. Planeamento Urbano e Arquitectura de Habitação em Olivais Sul (Lisboa, 1959-1969). Lisboa: Câmara Municipal de Lisboa.

Nunes, J. A., and N. Serra. 2004. "Decent Housing for the People: Urban Movements and Emancipation in Portugal." South European Society \& Politics 9 (2): $46-76$. 
Pinto, P. R. 2009. "Housing and Citizenship: Building Social Rights in Twentieth Century Portugal." Contemporary European History 18 (2): 199-215.

Pinto, P. R. 2013. Lisbon Rising: Urban Social Movements in the Portuguese Revolution, 1974-1975. Manchester: Manchester University Press.

Queirós, J. 2013. "Precariedade Habitacional, Vida Quotidiana e Relação com o Estado no Centro Histórico do Porto na Transição da Ditadura Para a Democracia." Análise Social 206: 102-133.

Raposo, I., and J. Malheiros. 2010. Concurso Público Internacional Para a Aquisição de Serviços de Elaboração do Plano de Pormenor da Cova da Moura: Programa de Trabalhos e Cronograma. Lisboa: Faculdade de Arquitectura e Instituto de Geografia e Ordenamento do Território.

Raposo, I., and J. Oppenheimer. 2007. Subúrbios de Luanda e Maputo. Lisboa: Colibri.

Robinson, J. 2011. "Cities in a World of Cities: The Comparative Gesture." International Journal of Urban and Regional Research 35 (1): 1-23.

Rowe, P. 1993. Modernity and Housing. Cambridge, MA: MIT Press.

SAAL. 1976. Livro Branco do SAAL-Volume 1. Lisboa: Conselho Nacional do SAAL.

SAAL Curraleira Team. 1984. "Designing Curraleira." In The Scope of Social Architecture, edited by C. R. Hatch, 265-269. New York: Van Nostrand Reinhold.
Salgueiro, T. B. 1977. "Bairros Clandestinos na Periferia de Lisboa." Finisterra: Revista Portuguesa de Geografia 12 (23): 28-55.

Straub, A. 2009. "Dutch Standard for Condition Assessment of Buildings." Structural Survey 27 (1): 23-35.

Turner, J. F. C. 1976. Housing by People: Towards Autonomy in Building Environments. London: Marion Boyars.

Turner, J. F. C., and R. Fichter, eds. 1972. Freedom to Build: Dweller Control of the Housing Process. New York: Macmillan.

Valladares, L. 2006. La Favela D'un Siècle à L'áutre: Mythe D'origine, Discours Scientifiques et Représentations Virtuelles. Paris: Éditions de la Maison des Sciences de l'Homme.

Vilhena, A., J. B. Pedro, and J. V. Paiva. 2011. "Método de Avaliação das Necessidades de Reabilitação: Desenvolvimento e Aplicação Experimental." Engenharia Civil 39: 5-21.

Yaneva, A. 2005. "Scaling Up and Down: Extraction Trials in Architectural Design." Social Studies of Science 35: 867-894.

Eduardo Ascensão is Postdoctoral Researcher at the Centro de Estudos Geográficos, University of Lisbon. Email: eduardoascensao@ campus.ul.pt 